\title{
SYNTACTIC AND LEXICAL ASPECTS OF STUDENTS' LEGAL TRANSLATIONS AT THE PostgraduATE LEVEL
}

Igor Lakić, University of Montenegro, igorlakic24@gmail.com

Original scientific paper

DOI: 10.31902/fll.33.2020.10

UDC: 811.111'25:34(497.16)

\begin{abstract}
Teaching translation of legal texts into English at the postgraduate level at the Faculty of Philology (formerly at the Institute of Foreign Languages), University of Montenegro, started in 2004. At this study programme, students face for the first time challenges of translating legal texts. Although they occasionally translate some legal texts at the undergraduate level, this is the first time that they study legal translation in a systematic way. This certainly produces some challenges, that may be mainly observed on two levels: (1) syntactic level, where some students produce English sentences that are literal translations of Montenegrin sentences; bearing in mind syntactic differences in the languages, this sometimes leads to a loss of meaning or distorted meaning in translations; and (2) lexical level, where there are differences in the English and Montenegrin legal systems, which certainly requires caution in translation; it is possible to identify some inconsistencies in using legal terminology because some Montenegrin concepts cannot be always simply transferred into English without looking more deeply into the legal systems. The paper discusses the notions of formal fidelity vs. fidelity to the "uniform intent" of the text (Šarčević, 1997) or what Hatim and Munday (2004) refer to as literal and free translation. These notions are crucial for my discussion of causes of errors in my students' translations.
\end{abstract}

Keywords: teaching legal translation, literal and free translation, syntactic errors, lexical errors

\section{INTRODUCTION}

Law is a very wide and comprehensive discipline which touches upon almost every aspect of our life and work. Everything around us is regulated in one way or another by law. This permeating feature of the field of law definitely means that doing legal translation requires entering different worlds, different fields and thus different registers.

People have always had to abide by some kind of rules. Rivlin (2004: 12) says that "humans have always as a matter of necessity lived by rules" in different parts of the world, in various ages and in simple or complex societies. These rules are usually known to us in the 
form of laws and regulations that are made for everyone, lawyers and lay persons. Harvey (2002: 178) rightfully claims that "one of the hallmarks of legal discourse is arguably that it is not restricted to specialists, but is ... intended for the lay citizen". Being intended for the lay citizen as well, legal texts should be clear and legible for everyone, but it is not always the case.

The difficulty of understanding the languages of many disciplines lies in the fact that they are different from one country to another. When it comes to legal language, Haigh (2004: xvi) recognises that the writing conventions in English compared to other languages are different and this includes structure of sentences, insufficient use of punctuation, foreign or unusual phrases etc. According to him, difficult words and phrases are also used. This is what may represent a difficulty in teaching translation of legal English texts.

However, there is much more to it. In teaching and learning legal translation it is necessary to teach and learn not only proper vocabulary and apply adequate syntax, but also to grasp the nuances of various legal systems and concepts that do not necessarily overlap and adapt them to the intent of the text. This makes teaching and learning legal translation a challenge but also an endeavour worth investing in.

Furthermore, Gao (2019: 269) says: "Scholars in this field try to analyse the concept composition of translation competence from such aspects as language knowledge, subject knowledge, cultural knowledge and cognitive psychological process of translation activities." This certainly means a much more comprehensive approach to teaching legal translation than it may seem at first.

The purpose of this paper is to present some challenges that one can encounter in teaching legal translation, primarily those at the syntactic and lexical level, which, directly or indirectly, reflect the intended meaning of the source text. At the syntactic level it is possible to notice that some students provide literal translations of Montenegrin sentences into English. The two languages differ in syntax and resorting to word-for-word translations contributes to a complete loss of meaning or distorts meaning. On the lexical level, one must be aware of the differences between the English and the Montenegrin legal traditions. It imposes a need for better understanding of the two systems. Without that, translation of Montenegrin concepts into English may cause additional inconsistencies and prevent understanding and interpreting legal norms. In addition, there are occasional grammar and morphological errors, which may point to omissions during the undergraduate study programme. 
In this paper I refer to my course Translation of Legal Texts from Montenegrin into English that I have taught for 16 years now to fourthyear students of translation at the Faculty of Philology (formerly the Institute of Foreign Languages), University of Montenegro ${ }^{1}$. Students are for the first time exposed to a full course in legal translation at the post-graduate level, although during their undergraduate study programme they encounter some bits of legal discourse in their translation courses, but not in a systematic way. The course Translation of Legal Texts into English is aimed at translating Montenegrin legal documents into English, mainly paying attention to the needs of the country in the process of the European integration. The intention is to start from some more "general" legal texts in Montenegro, such as declarations (The Declaration on the Accession to the European Union, the Declaration of the Independent Republic of Montenegro), and then proceed with more specific ones, such as the Constitution of Montenegro, the Law on State Administration, the Law on Local Self-Government, the Law on Courts, the Criminal Code etc. These are just broadly defined categories which do not include only the laws, as prescriptive documents, but also their interpretations, summaries etc. as descriptive ones ${ }^{2}$.

The structure of the paper is as follows. After the introduction, Part 2 deals with some theoretical and practical considerations, while Part 3 shows examples of syntactic and lexical errors in students' translations and discusses possible causes of such cases. Part 3 provides conclusions.

\section{SOME THEORETICAL AND PRACTICAL CONSIDERATIONS}

Much of the translation work in Montenegro, as well as in the whole region of the Western Balkans, is done for the purpose of the European integration, which implies adherence to the language rules defined by the EU. Thus, EU Regulation 1/1958 sets up the EU language regime that defines the official languages to be used by the EU, both by institutions and member states (Somssich, 2012: 39). All official languages of the EU are considered authentic languages so that any agreement, for example, drafted in any of these languages is a legally binding language version. In practical terms, it poses a requirement before translation trainers to observe the language used in these

\footnotetext{
${ }^{1} \mathrm{~A}$ broader description of the study programme in translation can be found in Lakić, I. and Pralas, J. (2016, pp. 87-118.

${ }^{2}$ See more about the distinction between prescriptive and descriptive texts in Harvey (2002, p. 179)
} 
versions. Since Montenegrin (along with Serbian and Bosnian) is not an official language of the EU until the country accedes this organisation, while Croatian $^{3}$ is, it is possible to take into consideration the Croatian - English versions of translated text, up to an extent, when looking into the generally accepted terminology in the EU, including the field of law.

Besides, the standards of the English Master's in Translation (EMT) support the idea of "convergence between training for translators in Europe" (EMT, 2009: 1), which is why it is necessary to take them into consideration when developing curricula for translation courses. The EMT standards provide "the definition of a true framework of reference, putting forward a minimum quality profile and specifying the competences necessary" (EMT, 2009: 1). The aim is to improve the quality of training translators. These standards have been incorporated into the Study Programme in Translation at the Faculty of Philology, University of Montenegro.

There is a variety of translation programmes within the EU, but also throughout Europe, apparently established in different settings and with diverse goals. Therefore, the EMT competences can serve as a guiding principle in developing translation curricula and defining the aspects necessary for training translators. The image below contains the competences for professional translators, experts in multilingual and multimedia communication:

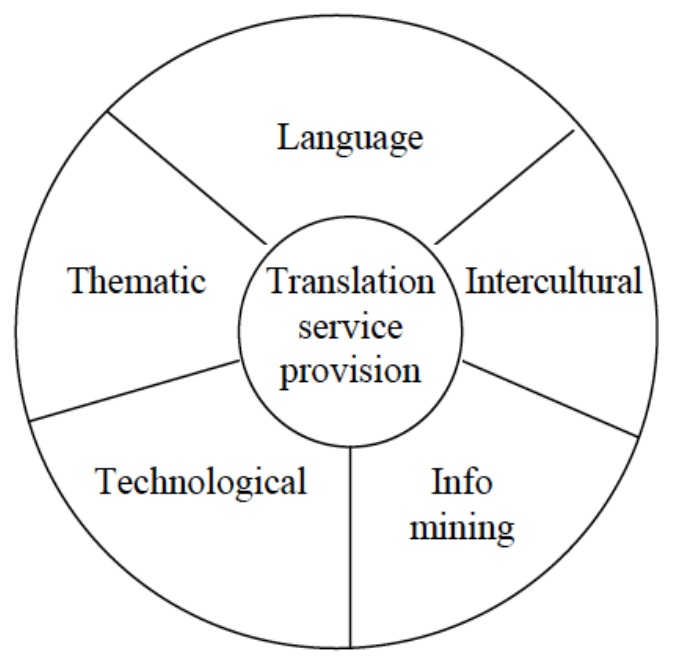

\footnotetext{
${ }^{3}$ Looking from the linguistic point of view, Montenegrin, Serbian, Bosnian and Croatian belong to the same language system.
} 
Image 1: EMT Competences for professional translators, experts in multilingual and multimedia communication $^{4}$

In this paper I will mainly concentrate on the language of law. Still, linguistic choices are not linked to the language competence only but depend on other competences. According to the EMT Expert Group (2009: 3) "the competences proposed in each of the six areas are interdependent".

Thus, the language of law can be an issue from many different points of view. Haigh (2006, p. xvi) says that "legal terms of art are technical words and phrases which have precise and fixed legal meanings and which cannot usually be replaced by other words". According to him, some of them are familiar to laypersons, such as patent, share, royalty, while others are known only to lawyers (e.g. bailment, abatement).

Another characteristic is that legal jargon also includes archaic words that are not used in the English we speak today (Haigh, 2006: $\mathrm{xvi)}$. These may include words such as hitherto, hereinafter, therein, bequest etc. He also mentions obscure words or phrases (e.g. Act of God, as per...) that are highly specialised and usually used only in the field of law.

One must not forget words that have different meanings in general English and legal English. For example, the noun power in general English stands for (a) ability, capacity or potential, or (b) strength, intensity, force, but in specialised registers, such as law, it denotes (c) command, authority, rule, control, influence, or (d) right, privilege, prerogative $^{5}$. It is advisable not to forget the writing and lexical distinctions between British an American English, too.

However, from the point of view of EMT standards, this is just the language aspect. It is not enough to know the differences in writing and terminology between the legal systems of the English speaking countries. The choice of terminology and style certainly depends on the target readers. It is much more important to know how to translate the Montenegrin text as a source text into an appropriate English text as a target one by transferring ideas rather than words.

Legal traditions differ among countries and legal translation therefore requires not only proper conveying of messages between two languages but often between different legal cultures as well as understanding of different worlds in which people live and function.

\footnotetext{
${ }^{4}$ https://ec.europa.eu/info/sites/info/files/emt_competences_translators_en.pdf

${ }^{5}$ Taken from Manser, M.H. (ed.) (1995) Paperback Thesaurus, Edinburgh: Chambers.
} 
According to Šarčević (1997: 71), this requires not formal correspondence between source and target text but equivalence in terms of legal effects of those texts. Šarčević (1997: 112) proposes that the translators should not stick to formal fidelity to the source text, but rather fidelity to the "uniform intent" of the text.

Hatim and Munday (2004: 10-14) also deal with this issue, using different terminology, though. They first mention the difference between form and content, saying that "the sense may be translated, while the form often cannot". This split between form and content in reflected in the two ways of translating - literal and free. Munday (2006: 19) also refers to these concepts as word-for-word and sensefor-sense translation.

This means that whatever terminology is used, the crucial point is not to adhere to the formal (linguistic) correspondence of the text but to convey notions or meanings in such a manner as to convey the intent of the text. This highly depends on the translator's "ability of contrastive analysis of the source text with the target one" (Gao, 2019: 270).

The Montenegrin Handbook for Translation of legal and other Acts in the Process of the European Integration ${ }^{6}$ tries to cope with this problem, at least partially, by providing a good reference material for the Montenegrin translators (Priručnik, 2010). The Handbook was done by a group of experts from the fields of law, linguistics and translation. The goal was to create a good legal and linguistic ground for translation of the "EU Questionnaire" that the country had to reply to before starting the negotiation process for accession to the EU, but the intention was also to use this tool for the further translation process throughout the negotiations. The Handbook provides quite comprehensive descriptions of the legal systems of Montenegro and the EU, as well as special instructions for translation of the European Union acts. It also presents examples of the EU legal documents and the legal acts of Montenegro, as well as the English Style Guide. The background knowledge on the field of law leads to a better understanding of the content without which the knowledge of vocabulary is mainly useless. In this way, translators, but also students of translation got the crucial instrument for embarking on the very demanding task of translating hundreds of thousands of pages.

\footnotetext{
${ }^{6}$ Priručnik za prevođenje pravnih i drugih akata u procesu evropskih integracija: https://vdocuments.mx/document/vlada-crne-web-view-prirunik-za-prevoenjepravnih-i-drugih-akata-u-procesu-evropskih.html
} 
The Handbook relates the detailed description of the legal systems of Montenegro and the EU, including their similarities and differences, and their crucial characteristics and notions with the issues of terminology, register, style. Thus, thematic and intercultural competences are linked to the linguistic one. For example, it discusses and explains the concepts of treaty, agreement, framework agreement, convention, charter, protocol, declaration etc. not only by providing appropriate translations but also by explaining them in detail. The authors also decided to clarify the notions of directive and regulation as used in the EU acquis. The proper Montenegrin translation for regulation could be uredba (decree), but the word regulativa in Montenegrin was chosen to distinguish between EU and Montenegrin legal documents. As for directive, the authors decided to adopt the term direktiva in the Montenegrin language to make it clear that it refers to the EU documents. These are just a few examples of how the authors facilitated the future work of translators, creating also a good basis for the training translators in the field of law.

Thus, when we come to the level of the language use, it turns out that different concepts can be managed provided the students understand the basics of the discipline. Without that, no explanation of isolated pieces of vocabulary could lead to a successful translation. That is why the students need to be equipped with some basic legal knowledge, which, in the case of the Montenegrin translation study programme, is acquired through the course Basics of Law, taught by a professor of law from the Faculty of Law, University of Montenegro, with an excellent knowledge of English. In addition, in translation classes their professors of translation, who are experienced translators and interpreters in the field of law, as well as court translators and interpreters, can provide important clarifications and explanations of the legal system in general and various legal notions.

Nevertheless, some problems occur along the way. Thus, I am faced with some errors in students' translations that we need to cope with jointly. It seems that the errors are often caused by word-forword approach to translation, a problem that I sometimes encounter in my students' translation, when the form prevails and the intended meaning is lost. As I have already mentioned, the errors are mainly syntactic and lexical. My work with students of translation has shown that syntactic errors usually distort the meaning expressed in the source text and in most situations this is due to the negative transfer or interference of Montenegrin into English. Additionally, it seems that lexical errors arise as a result of (a) a lack of understanding of the topic in general (e.g. the field of criminal legislation, labour relations etc.), 
and (b) different nuances within the topic (e.g. the difference among homicide, killing, murder, manslaughter etc. in criminal legislation).

There is a rich literature on errors in the field of second language acquisition ${ }^{7}$, but one can hardly find works dealing with errors in the legal translation process from Montenegrin into English. This is probably due to the fact that each discipline has its own characteristics that may lead to different types of errors. Thus, my conclusion that syntactic errors in my students' translation are result of a negative transfer, while lexical errors point to a lack of proper understanding of the text or the notions expressed in it, require additional research in order to see whether other colleagues encounter similar problems.

In the rest of the paper, I will deal with these two types of errors syntactic and lexical.

\section{COPING WITH ERRORS}

I would argue that the best way of coping with errors is knowledge of the discipline and the topic of the text that is translated. This requires extensive reading of similar texts before the students start with their own translation. My recommendation is that they first read the text that they have to translate and underline the ideas that are not clear and the terminology that they do not know. After that, I suggest to them reading similar British or American texts as well as the acts of the European Union, depending on who the target audience is. Through the reading process, students may pick up appropriate terminology but also useful phrases. It is only then that they should start the translation process. The final outcome is usually satisfactory, but in some situations syntactic and lexical errors may distort the intended meaning. The errors presented here are the most serious ones, found in a very limited number of translations. Still, they require additional consideration and work with the students who make such errors.

\section{Syntactic errors}

According to linguistic typology, there are analytic and synthetic languages. An analytic language is the language "in which separate words realize grammatical distinctions that in other languages may be realized by inflections" (Matthews, 1997: 17). The latter refers to synthetic languages "in which grammatical distinctions are realized by inflections" (Matthews, 1997: 369). Typically, analytic languages have a low morpheme-per-word ratio, especially with respect to inflectional

\footnotetext{
${ }^{7}$ See: Richards, J.C. (1984)
} 
morphemes. A grammatical construction can similarly be analytic if it uses unbound morphemes, which are separate words, or word order" ${ }^{\prime 8}$.

English belongs to the so-called analytic languages in which "subject-verb-object order is relatively inflexible because it identifies which part of the sentence is the subject and which one is the object" 9 . Thus, the following two sentences - Tom bit the dog and The dog bit Tom - are completely different in meaning, because it is clear what is the subject and what is the object in each sentence respectively.

However, the situation is more complex in synthetic languages where word order is not strictly defined as in analytical languages. Montenegrin belongs to this group. Owing to the inflective morphemes it is possible to have different positioning of parts of sentences without losing the intended meaning.

The difference between Montenegrin and English in terms of the word order in sentences sometimes represents a problem in translations of Montenegrin texts into English and I will point to such problems in the following examples.

The Law on Local Self-Government of Montenegro, Article 41, defines the right of the president of municipality ${ }^{10}$ to propose decisions, regulations and general acts. The sentence reads as follows: Pravo predlaganja odluka, drugih propisa i opštih akata ima predsjednik opštine...

One of the tests I marked contained the following translation:

* The right to propose the decision, other regulations and general acts has the president of the municipality. ${ }^{11}$

This is a literal translation of the Montenegrin sentence into English which follows the Montenegrin word order. Actually, here the president of municipality should be the subject of the English sentence. However, the student probably did not find the translated sentence unusual due to a clear meaning he/she had in Montenegrin. This may indicate a lack of competence in L2 translation. This certainly is a challenge that has to be dealt with in classes in order to avoid similar situations. In addition, this is probably the most frequent case of syntactic errors that I can find in students' translations

Similarly, the next example can be classified in the same group of errors. This example is from the Constitution of Montenegro, Article

\footnotetext{
${ }^{8}$ https://en.wikipedia.org/wiki/Analytic_language

${ }^{9}$ https://en.wikipedia.org/wiki/Subject\%E2\%80\%93verb\%E2\%80\%93object

${ }_{10}$ In the Montenegrin legal system there is a difference between "president of municipality" and "mayor", because only the capital Podgorica and the old historic capital Cetinje have mayors, while other municipalities have presidents.

$11 *$ is used for incorrect sentences, phrases or words
} 
86, which defines that, in addition to MPs, the President of Montenegro, Prime Minister, members of the Government etc. also enjoy immunity. In the English translation, immunity is the object of this sentence:

Imunitet, kao i poslanik, uživaju: predsjednik Crne Gore, predjednik i članovi Vlade...

There are several wrong translations of this sentence:

* Immunity, apart from the councillors, enjoys the President of Montenegro, the president and the members of the Government...

* Immune system, as well as the minister, enjoy the president of Montenegro, the president and Government members...

* Immunity, along with the MP, enjoy: The President of Montenegro, the Prime Minister and members of the Government...

Apart from some obvious lexical errors (e.g. councillors, immune system, president of government), all these translations start with what should be the object of the sentence. It would be possible, though, to keep this order, but with the verb enjoy in the passive voice, but it was not used.

Using passive forms seems to be another challenge, closely connected with examples like this. In the next example, it is also possible to either change the word order or use the passive voice. This provision of the Constitution of Montenegro, Article 150, defines that a court, another state body etc. may initiate the procedure for assessing constitutionality and legality before the Constitutional Court:

Postupak pred Ustavnim sudom za ocjenu ustavnosti i zakonitosti može da pokrene sud, drugi državni organ...

Here are two examples of wrong translations:

* The procedure before the Constitutional Court for the assessment of constitutionality and legality can initiate a court, other state body...

* Procedure for the evaluation / assessment of constitutionality and legality can / may initiate a court.

The sentence should be translated either by putting court, other state body in the subject position in the sentence or by putting the verb initiate in passive (may be initiated by).

The following Montenegrin sentence, taken from the Constitution of Montenegro (Article 86) stipulates that criminal or any other proceedings may not be initiated against an MP for expressing his/her opinion. The Montenegrin sentence:

Poslanik ne može biti pozvan na krivičnu ili drugu odgovornost ili pritvoren za izraženo mišljenje...

was translated as follows:

* Against MP shall not be prosecuted any criminal procedure... 
Apart from the wrong use of the verb prosecute instead of initiate (criminal proceedings) or be held criminally liable, the translation again follows the word-for-word order of the Montenegrin sentence.

The following sentence further points to some problems in translation. The original Montenegrin sentence is from the Law on State Administration, Article 45:

U organu uprave može se postaviti jedan ili više pomoćnika starješine organa uprave.

The translated sentence does not have the subject before the verb:

* In administration body may be appointed one or more assistants to the head of an administration body.

Obviously, word order is the same as in the Montenegrin sentence, which could be properly translated as:

One or more assistants to the head of an administration body may be appointed in an administration body.

Another group of problematic translations also reflects the problem with the English sentence structure. Paragraph 1, Article 8 of the Montenegrin Constitution, defines that any direct or indirect discrimination on any grounds shall be prohibited:

Zabranjena je svaka neposredna ili posredna diskriminacija, po bilo kom osnovu.

The following translation is obviously problematic:

* It is prohibited every direct or indirect discrimination.

Actually, the Montenegrin sentence does start with "Zabranjena je" (/t is prohibited...), but this Montenegrin construction requires subject in the first position in the English sentence, which, in this case is direct or indirect discrimination.

The same Article, paragraph 2, reads as follows:

Neće se smatrati diskriminacijom propisi i uvođenje posebnih mjera...

The translation provided was:

* It shall not be considered discrimination the regulations and introduction of special measures...

Again, regulations and special measures should be the subject of the sentence in the English translation.

As I have said, these examples are taken from the tests of just a small number of students, but they point to the fact that some students obviously do not come to the postgraduate level with adequate knowledge of English grammar and English syntax. Another reason could be that despite the knowledge of the rules, they do not know how to use them in real linguistic situations. Therefore, in grammar and syntax classes much more attention should be paid to the differences between languages. My experience shows that 
students grasp these differences by contrasting their mother tongue with English. This can be best done when they are exposed, in their grammar and syntax classes, to translating ready-made sentences from their mother tongue into English. These sentences may be made, among other things, based on typical errors, such as the ones shown above, which students make not only in their translations but also in essays. The way to their eradication through translation is then definitely much easier.

\section{Lexical errors}

In dealing with terminology, attention must be paid not only to the differences between the Montenegrin and English legal systems, but also to differences among the legal systems of the English-speaking countries, which all belong to the same legal tradition of common law. Their legal systems may differ up to a point, but the terminology used can be different too. It is therefore necessary to point, for example, to the notions of misdemeanour, petty crime, delict and contravention in these legal systems. Students should be made aware of these differences in order to be able to apply them when translating texts for different clients, adapting the vocabulary to the specific legal system that the target text is intended for.

Thus, a distinction should be made when it comes to adjectives such as responsible, accountable and liable, especially because there is only one word used in Montenegrin (odgovoran) for these three words. Due to a lack of knowledge, students tend to confuse these three concepts and a clear explanation with examples has to be provided to them so that they can use them properly.

They sometimes do not distinguish between rulebook (pravilnik) and rules of procedure (poslovnik), although these refer to two different types of documents.

Occasionally, it is possible to find some omissions in the Montenegrin legal texts so the terms used can be misleading. For example, the word usvojiti is translated into English as adopt or pass (a law), but a mayor cannot adopt but rather issue an act, although the Montenegrin word usvojiti is used for issue in this context. Here, even the Montenegrin word is wrong, as adopt would rather require a voting procedure. This means that more attention should be paid to the real meaning and context (or co-text) of words and sentences, which is possible only when students have some knowledge of the legal system and procedures.

The words that are also often confused are nomination, appointment and election. Here, Montenegrin offers different nouns 
(kandidovanje, imenovanje / postavljenje i izbor) but students still confuse them occasionally, which requires additional background knowledge to use them properly.

The difference between proposition (offer) and proposal (plan, usually written) requires additional explanation. The same goes for proceedings and procedure where it is necessary to distinguish between court proceedings and administrative procedure, for example.

The scope of English words that could replace Montenegrin verbs odbiti, poništiti, proglasiti nevažećim, ukinuti and opozvati is quite extensive. The students should therefore do small research in order to properly translate these words into English. Thus, it is possible to:

- decline enforcement of an individual act;

- annul an official agreement, decision or result, as well as elections or marriage;

- abolish a system, practice or institution;

- revoke or officially cancel a decree, decision or promise;

- repeal a law or an act of parliament;

- suspend or temporarily prevent from continuing or being in force or effect; or

- withhold or refrain from giving or granting such as payment or deduct a tax.

The same goes for the Montenegrin noun uslovi, which has different English variations:

- terms refer to provisions that determine the nature and scope of an agreement;

- conditions refer to the factors or prevailing situation influencing the performance or outcome of a process; while

- requirement is something compulsory, a necessary condition.

These kinds of issues can be quite demanding. In addition, some of the examples mentioned previously in the text show that even simple terms, such as predsjednik vlade (prime minister), can be translated literally as president of government.

In terms of parts of speech, there can be occasional errors. In the noun phrase neposredno viši sud, the translation *imminent high court is a completely wrong translation. Imminent cannot be used in this context. What the Montenegrin phrase suggests is immediately higher court, or a higher judicial instance (for example, in the Montenegrin system the Supreme Court is immediately higher court for the High Court). Besides, there is a wrong part of speech in this phrase (adjective instead of adverb). The word imminent was probably used 
here because in the phrase imminent war danger the Montenegrin word neposredno would be also used.

These examples show that working with the legal vocabulary is quite a challenging task for both teachers and students, who must work together in coping with problems. In addition to providing the necessary explanations of legal notions, teachers are there to guide students through this process by explaining how come up with the best solutions as well as to develop students' critical thinking. On the other hand, students should be ready to do additional reading of legal texts in order to grasp legal concepts. They also have to be ready to search different sources, including the online ones. Classes should be organised as workshops and include discussion on different options, so that decisions on best translations can be reached jointly.

\section{CONCLUSION}

Legal profession is a wide field that permeates all aspects of life, different professions and occupations. In addition, legal systems differ (e.g. civil law and common law), but there are also differences within these legal systems in terms of concepts and terminology.

It is therefore quite challenging to teach legal translation, as it requires knowledge of the profession in general, but also the knowledge of different aspects or branches of law. In the world of constant changes, which are followed by changes in legislation, this can be quite a demanding task. Thus, the job of a lawyer, but also that of a trainer of legal translation is a never ending story. We can then imagine how difficult it can be for students of legal translation, who have to acquire both the knowledge of law in general, the knowledge of different legal systems and apply appropriate syntax and vocabulary to convey the intended meaning into a foreign language, or vice versa.

In this paper, I have tried to show what kind of syntactic and lexical challenges I encounter in my work with students of legal translation. They point to the fact that word-for-word translation may distort the meaning and that sense-for-sense translation is definitely the best approach. In other words, formal fidelity to the source text can be a wrong path to a good translation, although some fidelity must be kept, while fidelity to the intent of the text is the right way to proceed with translation. However, it is hard to expect that students can succeed in providing a complete sense-for-sense translation from the start. Formal translation will certainly be present and students will gradually improve both their knowledge of law and their language skills.

The examples I used were taken from students' translations of various legal texts, although these are exceptions rather than a rule. 
Still, we do need to work with the exceptions and lead students to reach the level of expertise that can make them competitive on the labour market of translation. Although demanding, this process can be a rewarding task benefiting not only students but also teachers who can learn a lot along the way, too.

\section{References}

Dumančić, G. and Šoštarić, B. (2017) "EU tax legislation in English, Croatian and German: A comparative analysis of frequently used words and phrases, orthography, pragmatics and syntax". In Hieronymus, 4 (2017), 129-156.

EMT Expert Group (2009). Competences for Professional Translators, Experts in Multilingual and Multimedia Communication. Retrieved on April 24, 2020 from https://ec.europa.eu/info/sites/info/files/emt_competences_tran slators_en.pdf

Gao, L. (2019). A two-dimensional hypothetical model for legal translation competence enhancement. In: Current Trends in Translation Teaching and Learning E, 6, 269-305.

Haigh, R. (2006). Legal English. London: Cavendish Publishing.

Harvey, M. (2002). "What's so Special about Legal Translation?". In Meta, XLVII, 2.

Hatim, B. (2001) Teaching and Researching Translation. Harlow: Pearson Education.

Hatim, B. \& Munday, J. (2004) Translation, An advanced resource book. London and New York: Routlege.

Lakić, I. \& Pralas, J. (2016). "Translation Training for the EU: The Case of Montenegro". In Current Trends in Translation Teaching and Learning $E, 3,87-118$.

Manser, M.H. (ed.) (1995). Paperback Thesaurus, Edinburgh: Chambers.

Matijašević, M. (2014) "Pravno prevođenje u svjetlu teorije skoposa". In Hieronymus, 1 (2014), 105-122.

Matthews, P.H. (1997) Oxford Concise Dictionary of Linguistics. Oxford: Oxford University Press.

Munday, J. (2006). Introducing Translation Studies: Theories and Applications. London and New York: Routledge.

Rivlin, G. (2004). Understanding the Law. Oxford: Oxford University Press.

Somissich, R. (2012). Studies on Translation and Multilingualism, Language and Translation in International Law and EU Law. Final report, 6/12. Luxembourg: Publications Office of the European Union. 
Priručnik za prevođenje pravnih i drugih akata u procesu evropskih integracija (2010). Podgorica: Vlada Crne Gore, Ministarstvo za evropske integracije Crne Gore.

Pym, A. et al. (2012). Studies on Translation and Multiligualism, The Status of the Translation Profession in the European Union. Final report, 7/12. Luxembourg: Publications Office of the European Union.

Richards, J.C. (1984). Error Analysis, Perspective on Second Language Acquisition. London and New York: Longman.

Šarčević, S. (1997). New Approach to Legal Translation. The Hague/London/Boston: Kluwer Law International.

Internet sources:

https://en.wikipedia.org/wiki/Analytic_language

https://en.wikipedia.org/wiki/Subject\%E2\%80\%93verb\%E2\%80\%93obj ect

https://ec.europa.eu/info/sites/info/files/emt_competence_fwk_2017 _en_web.pdf

\section{SINTAKSIČKI I LEKSIČKI ASPEKTI STUDENTSKIH PREVODA PRAVNIH TEKSTOVA NA POSTDIPLOMSKOM NIVOU}

Nastava prevoda pravnih tekstova na engleski jezik na postdiplomskom nivou na Fllološkom fakultetu (ranije na Institutu za strane jezike) Univerziteta Crne Gore počela je 2004. godine. Na ovom studijskom programme studenti se po prvi put suočavaju sa izazovima prevođenja pravnih tekstova. lako na dodiplomskom nivou oni povremeno prevode neke pravne tekstove, na postiplomskom nivou oni po prvi put izučavaju prevođenje pravnih tekstova na sistematičan način. Ovo svakako stvara određene izazove koji se mogu uočiti na dva nivoa: (1) sintaksičkom, gdje studenti nude prevode rečenica na engleskom koji predstavljaju bukvalni prevodi crnogorskih rečenica; imajući na umu sintaksičke razlike između dva jezika, ovo ponekad vodi do gubitka značenja ili iskrivljenog značenja u prevodima: i (2) leksičkom, s obzirom na postojanje razlika u pravnim sistemima zemalja engleskog govornog područja i Crne Gore, što svakako zahtijeva oprez u prevođenju; moguće je uočiti određene nedosljednosti u korišćenju pravne terminologije, jer određeni crnogorski koncepti ne mogu se jednostavno prebaciti na engleski bez dublje analize pravnih sistema. Ovaj rad razmatra pojmove formalne korespondencije u odnosu na korespondenciju koja se odnosi na "istovjetnu namjeru" teksta (Šarčević, 1997) ili ono što Hatim I Munday (2004) nazivaju bukvalni i 
slobodni prevod. Ovi pojmovi ključni su u analizi uzroka grešaka studentskih prevoda.

Ključne riječi: nastava prevoda pravnih tekstova, bukvalni i slobodni prevod, sintaksičke greške, leksičke greške 